\title{
透析患者における体位変換時の循環動態
}

\author{
丸山圭史馬㴊 非砂夫青木 正* 垣 内 孟 \\ 中 橋 弥 光* \\ 西陣病院内科 同泌尿器科*
}

(昭和 63 年 11 月 14 日受付)

key words：起立性低血圧，常時低血圧，自律神経機能，血液透析，hypovolemia

〈要旨〉

透析患者の起立性低血圧の機序を検討するために体位変換時の循環動態の計測を行った，対象は維持透析患者 10 例, うち糖尿病合併例 3 例で, 男 5 , 女 5. 年齢は 56 79 歳. 透析期間は 4 か月以下 5 例, 1 年以上 5 例. 透析終了 後に起立性低血圧症をきたす 2 例を含む常時低血圧 4 例, 正常血圧例 5 例, 高血圧例 1 例. 非透析日にSwan-Ganz 力 テーテルを㨀入し, tilting table の角度を, $0^{\circ}, 10^{\circ}, 20^{\circ}, 30^{\circ}, 45^{\circ}, 60^{\circ}, 90^{\circ}$ の順に増加させ, 各 5 分後の心拍出量と 血圧を測定した。

1) $0^{\circ}$ と $90^{\circ}$ のみを比較すると, 糖尿病の 3 例を含む 5 例で $20 \mathrm{mmHg}$ 以上の收縮期血圧 (systolic blood pressure, SBP) の低下を, うち 2 例で $40 \mathrm{mmHg}$ 以上の低下を認めたが, 自覚症状は出現しなかった。また透析後起立性低血 圧症の症例では末梢血管抵抗 (total peripheral resistance, TPR) は著明に上昇し, SBP はあまり変化しなかった。

2) $20 \mathrm{mmHg}$ 以上の SBP 低下例は角度の増加に対する SBP の变化から 2 つのグループに分けることができた。 2 例では $10^{\circ}$ で SBP が著明に低下し，20以上ではほぼ一定であった。3 例では $0 \circ$ から $30^{\circ}$ まで SBP はほぼ一定で， 以後角度の増加とともに直線的に低下した， $0^{\circ}$ と $90^{\circ}$ のPR を比較すると前者では低下，後者では軽度の増加を認め た。 また同様に心係数 (cardiac index, Cl) を比較すると前者ではほぼ不変, 後者では著明に低下した.

3 ) 透析期間で比較すると 4 か月以下の症例に対して 1 年以上の症例では, 卧位の SBP, TPR が低值で Cl は高值 であった．また起立後の SBP, Cl の低下はむしろ軽度であった。

以上の結果より，透析患者では安静時血圧と無関係にしばしば無症候性の起立性低血圧をきたす場合があり，弚の 原因として自律神経機能障害のみならず hypovolemia の関与も推定した。

\section{Hemodynamics in hemodialysis patients during postural change}

Yoshifumi Maruyama, M. D., Hisao Mabuchi, M. D., Tadashi Aoki, M. D*., Takeshi Kakiuchi, M. D., Hisamitsu Nakahashi, M. D.*

Departments of Internal Medicine and Urology*, Nishijin Hospital

Hemodynamics during postural change were evaluated to clarify the mechanism of orthostatic hypotension in hemodialysis (HD) patients. We studied 10 patients (five male, five female), aged 56-79, including 3 with diabetic nephropathy. The duration of HD was less than 4 months in 5 patients and more than one year in 5 . Four patients were hypotensive, including 2 with symptomatic orthostatic hypotension after HD, 5 were normotensive and one was hypertensive. Cardiac output and blood pressure were measured at the following angles $0,10,20,30,45,60$ and 90 degrees, with the patient remaining at each angle for $5 \mathrm{~min}$.

1) Comparing 0 and 90 degrees, systolic blood pressure (SBP) decreased more than $20 \mathrm{mmHg}$ in 5 patients, including 3 with diabetes mellitus, and SBP decreased more than $40 \mathrm{mmHg}$ in 2 of 5 patients who were asymptomatic. Total peripheral resistance (TPR) increased markedly and SBP did not change in 2 patients who showed orthostatic hypotension after HD.

丸山圭史 西陣病院内科

干 602 京都市上京区五过通六軒町西入溝前町 $1035(075-461-8800)$
2) Five patients, whose SBP decreased more than 20 $\mathrm{mmHg}$, were divided into 2 groups according to the change in SBP at increasing angles. SBP decreased 
markedly at 10 degrees but did not change at bigger angles in 2 of 5 patients. On the other hand, SBP was constant from 0 to 30 degrees, but decreased in a linear pattern at bigger angles. Comparing 0 and 90 degrees, TPR decreased in the former, but increased slightly in the latter. Cardiac index (Cl) did not change in the former, but decreased markedly in the latter.

3) The patients with HD for more than one year showed lower SBP, lower TPR and higher Cl in the supine position than those with HD for less than 4 months. The former showed smaller decreases in SBP and $\mathrm{Cl}$ in the standing position than the latter.

These results revealed frequent asymptomatic orthostatic hypotension in HD patients without relation to the blood pressure in the supine position. It is suggested that hypovolemia, in addition to autonomic imbalance, contributes to orthostatic hypotension in HD patients.

\section{緒言}

血液透析 $(\mathrm{HD})$ 患者の重要な合併症の 1 つとして最 近特に常時低血圧が問題となっているが, quality of life の観点からみれば起立性低血圧症もまた重要な問題と思 われる。これまで起立試験や tilting test は主として， HD 患者にみられる常時低血圧や透析低血圧に扔ける自 律神経機能検査の 1 つとして広く行われてきた ${ }^{1 \sim 4)}$.しか し起立性低血圧の観点から $\mathrm{HD}$ 患者の体位変換時の, 特 に角度の変化に対する循環動態については，詳細な報告 をみない。そこで今回我々は特に臥位から立位への小刻 みな角度の変化に対する循環動態の計測を中心に, $\mathrm{HD}$ 患者に括ける起立性低血圧の機序に関して検討を行った ので報告する。

\section{対象}

対象は維持透析患者 10 例 (男 5 例，女 5 例)。年齢は $56 \sim 79$ 歳, 平均 69.6 歳. 今回の計測前 1 週間の $\mathrm{HD}$ 前 の収縮期血圧 (systolic blood pressure, SBP) から, 低 血圧 $(\mathrm{SBP} \leqq 100) 4$ 例, 正常血圧 $(100<\mathrm{SBP}<160) 5$ 例, 高血圧 $(160 \leqq \mathrm{SBP}) 1$ 例に分類した。低血圧症例の うち症例 6, 9 注頻回に HD 後起立性低血圧症を呈し, また高血圧例は nifedipine 1 日 $15 \mathrm{mg}$ を投与中であっ
た。なお $\mathrm{HD}$ 時間は 1 回 5 時間，週 3 回，HD 期間の平 均は 21.6 か月で, 10 例中 5 例は 4 か月以下, 5 例は 1 年 以上であった。また，明らかな心機能低下を有する症例 は除外した (表 1 ).

\section{方法}

非透析日に Swan-Ganz カテーテルを挿入し tilting table の角度を $0^{\circ}$ から順に, $10^{\circ}, 20^{\circ}, 30^{\circ}, 45^{\circ}, 60^{\circ}, 90^{\circ}$ と変化させた。実施にあたっては各々の角度を 5 分間 保った後, 3 回心拍出量を計測した. そして毎回 $0^{\circ}$ には 戻さず, 8 分間隔で角度を増し, 測定をくり返した。ま た心拍出量と同時に上腕で非観血的に血圧を測定し, 平 均值を求めた。なお, $0^{\circ} に お け る$ 肺動脈圧及び肺動脈揳入 圧はいずれも正常範囲内であった。

\section{結果}

1 ) 収縮期血圧 (systolic blood pressure, SBP) の変 化

$0^{\circ}$ と $90^{\circ}$ を比較すると症例 $1 \sim 3,7,10$ (起立性低血 圧群) で, $20 \mathrm{mmHg}$ 以上の $\mathrm{SBP}$ の低下を認めた。 こ のうち症例 1,7 (N群) では, $0^{\circ}$ から $10^{\circ} て ゙$ 著明に低下 し, それ以上の角度では活涩一定であったのに対し, 逆 に症例 $2,3,10$ (H群) では $0^{\circ}$ から $30^{\circ}$ までがほぼ一定

表 1 対象患者の年齢, 性, 血圧, 透析期間, 原疾患を示寸. DM は diabetes mellitus, CGN は chronic glomerulonephritis である。

\begin{tabular}{rcclcl}
\hline Case & Age & Sex & \multicolumn{1}{c}{ BP } & Duration of HD (month) & \multicolumn{1}{c}{$\begin{array}{l}\text { Original } \\
\text { diseases }\end{array}$} \\
\hline 1 & 71 & F & Normotension & 77 & DM \\
2 & 79 & M & Nomotension & $<1$ & renal sclerosis \\
3 & 72 & F & Normotension & $<1$ & DM \\
4 & 66 & F & Normotension & 26 & CGN \\
5 & 62 & M & Hypertension & 4 & cystic disease \\
6 & 74 & F & Hypotension & 25 & renal sclerosis \\
7 & 61 & M & Hypotension & 1 & tuberculosis \\
8 & 79 & F & Hypotension & 12 & renal sclerosis \\
9 & 76 & M & Hypotension & 53 & renal sclerosis \\
10 & 56 & M & Normotension & $<1$ & DM \\
\hline
\end{tabular}



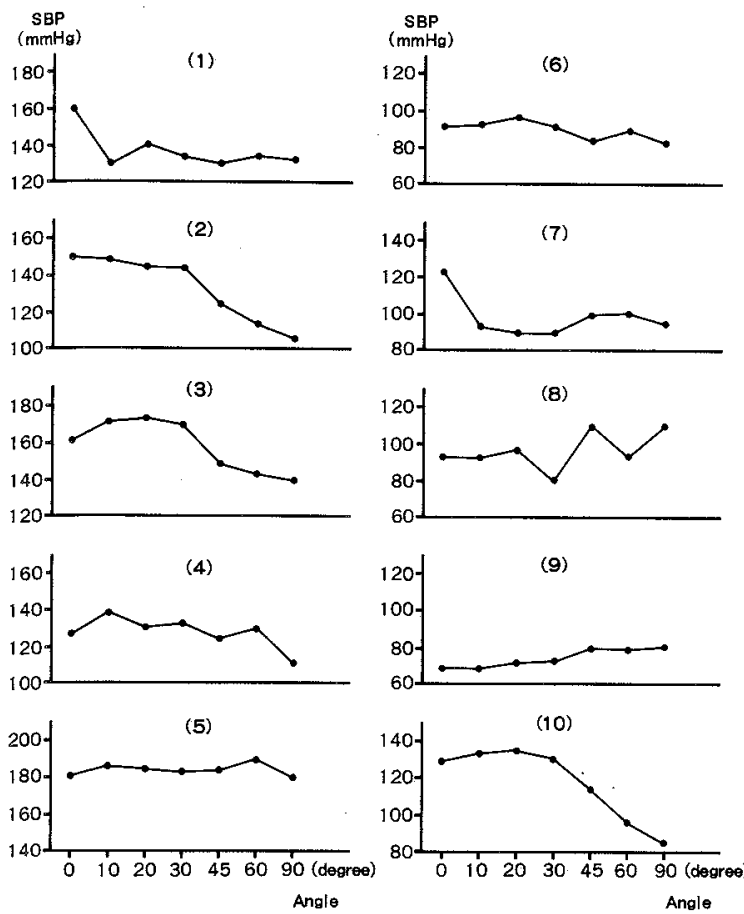

図 1 角度の変化に対する収縮期血圧 (systolicblood pressure, SBP) の変化を示す。なお （1）〜(10) は表 1 の症例番号に一致し, 以下同様である。

で，以後角度の増加とともに直線的に下降するという 2 つの pattern を認めた。しかし HD 後に起立性低血圧を 呈した症例 6,9 では今回の検查では角度の増加に対し て著明な低下を認めなかった（図 1 )。

2 ) 心拍数 (heart rate, HR) の変化

HR は全体として不変〜軽度上昇した（図 2 ）。

3 ) 心係数 (cardiac index, CI) の変化

症例 $2 \sim 4 ， 6 ， 10$ で角度の増加とともに著明な低下 を認めたが，他はほぼ不変であった。な招起立性低血圧 群においては，N群に比べH群で角度の増加とともに著 明な低下をみた（図 3 )。

4) 1 回心拍出係数 (stroke index, SI) の変化 ほぼCI と同様の変化を認めた（図 4 ).

5 ) 末梢血管抵抗 (total peripheral resistance, TPR) の変化

角度の増加に対しで特に一定の傾向はみられなかっ た。ただ起立性低血圧群のうち N群では, 減少後増加, H群では増加後一定ないし低下という傾向を示した（図 $5)$.

6 ) 全例で $0^{\circ}$ と $90^{\circ}$ のを比較した場合には, $90^{\circ}$ で有意 に SBP は低下，HR は上昇，CI は低下，SI は低下，
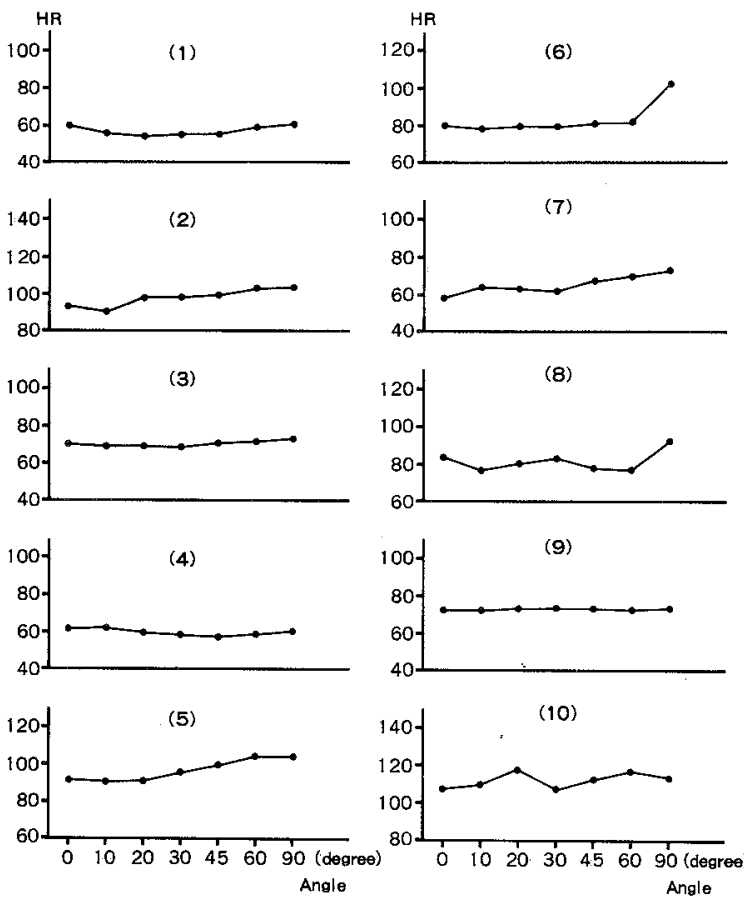

図 2 角度の変化に対する心拍数 (heart rate, HR) の変化を示す。

TPR は上昇した（図 6 ）。

7) 各症例別に $0^{\circ}$ に対する $90^{\circ}$ の相対的変化を比較し た場合，N群では TPR 低下，H群では 20\%以下の増加 を示した（表 2 )。このうち $40 \mathrm{mmHg}$ 以上の SBP 低下 例（症例 2，10）では，特にCI の低下が顕著であった。 しかし HD 後起立性低血圧をきたした 2 例のうち症例 6 では， CI の著明な低下に対して，TPR と HR の増加 も著明であり，また症例 9 では CI と HR はほほほ不変で あるのに対して，特に TPR の増加が著明でいずれも SBP は汪とんど変化しなかった。

8) HD 期間により 4 か月以下のグループ ( $\mathrm{S}$ 群) と 1 年以上のグループ (L群) に分け，0と $90^{\circ}$ のを比較 した場合，臥位の SBP はL群の方が低い傾向がみられ たが，起立時の SBP の低下の程度は S 群の方が顕著で あった（図 7 )。また臥位のCI はL 群の方が高い傾向に あったが，起立時の低下は S 群で顕著であった。さらに 臥位の TPR はS 群の方が高く，起立時にはその較差が より明瞭となった。

\section{考察}

一般に起立時に $300 \sim 800 \mathrm{~m} l$ の血液が下半身の静脈 に pool すると言われており，いわゆる機能的体内出血 

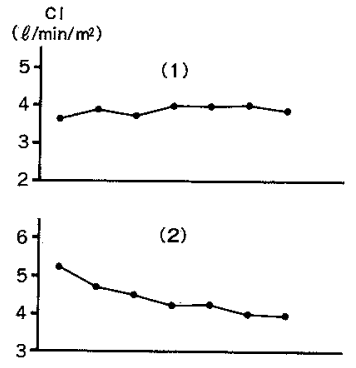

(3)
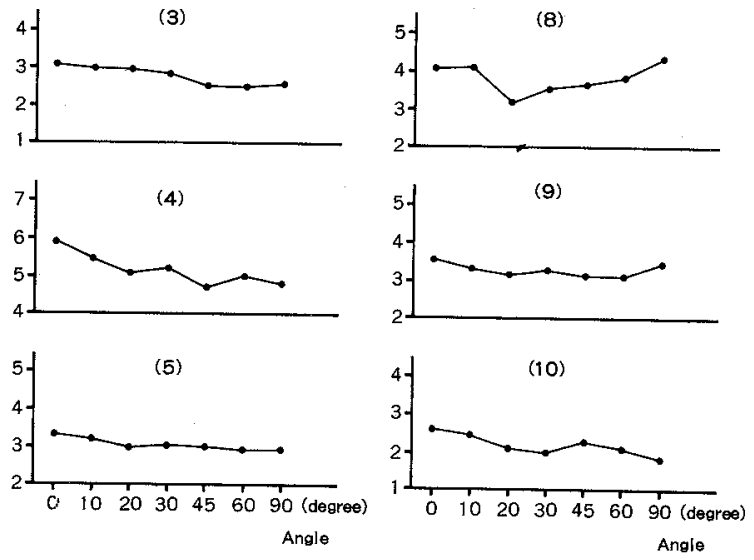

図 3 角度の変化に対する心係数（cardiac index, CI) の変化を示す。
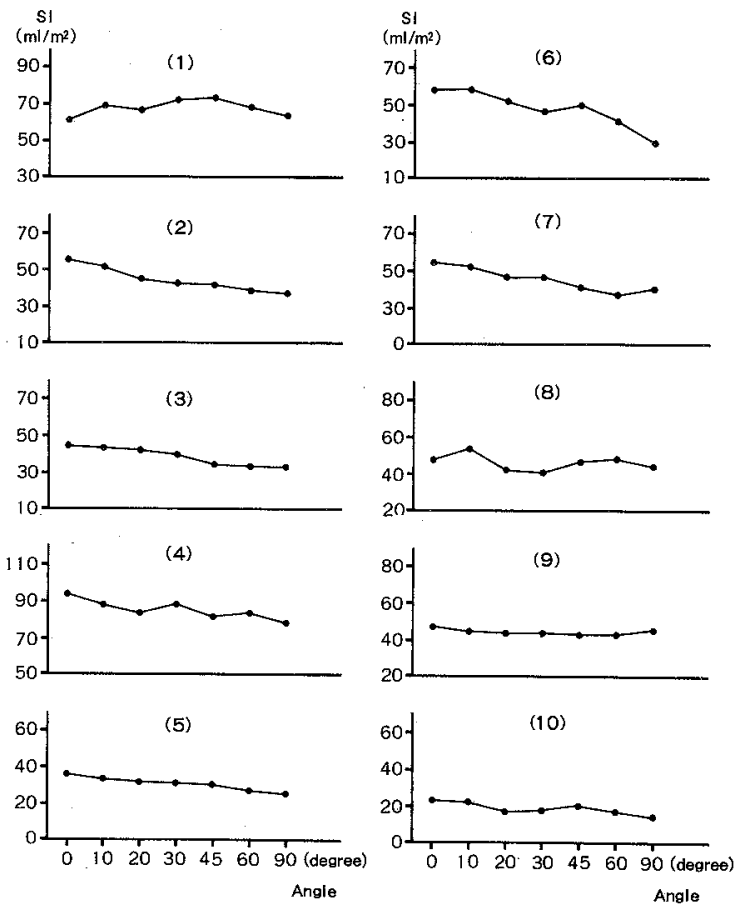

図 4 角度の変化に対する 1 回心拍出係数 (stroke index, SI) の変化を示す.
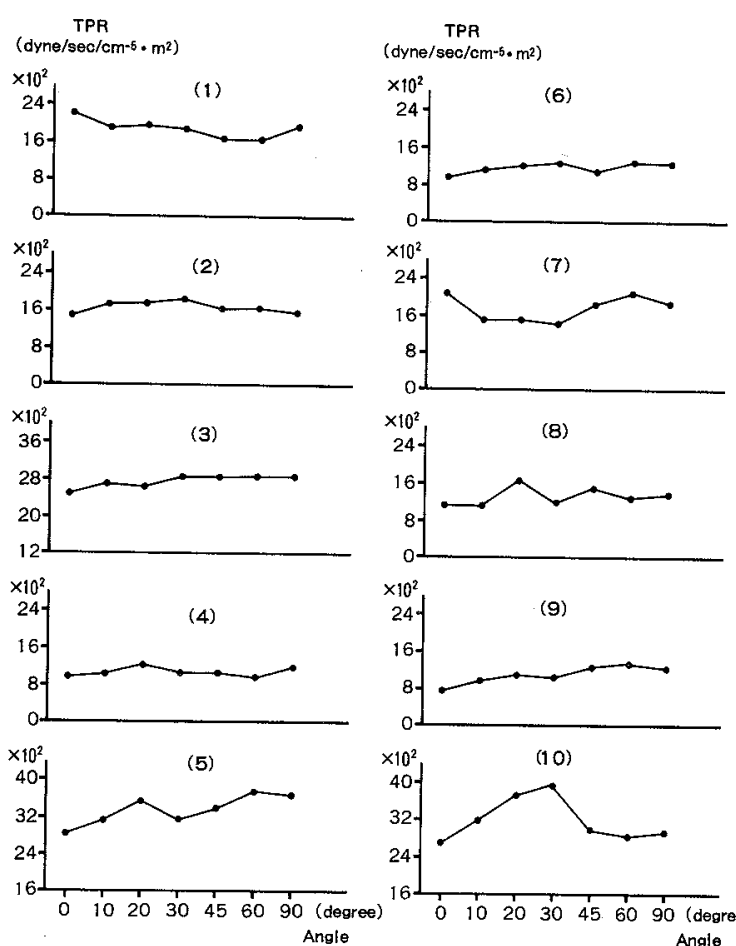

図 5 角度の変化に対する末梢血管抵抗 (total peripheral resistance, TPR)の変化を示す。

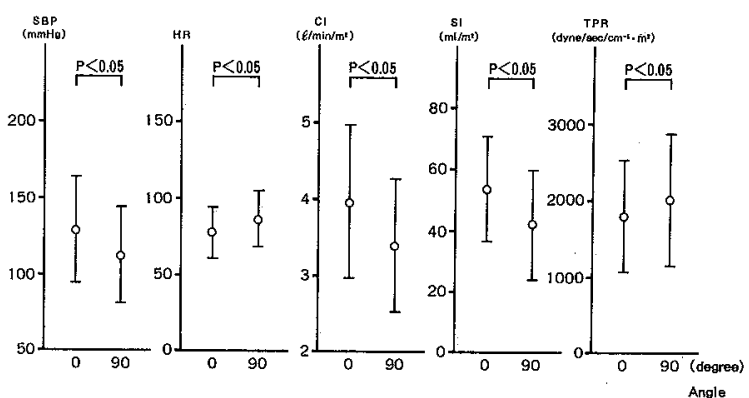

図 6 全例における $0^{\circ}$ と $90^{\circ}$ の血行動態諸標の変 化を示す。

$\mathrm{N}=10(\mathrm{M} \pm \mathrm{SD})$

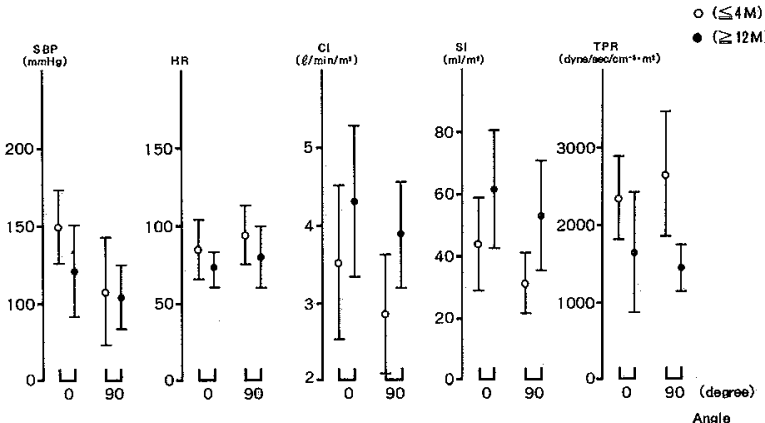

図 $7 \mathrm{HD}$ 期間が 4 か月以下 $(\mathrm{O})$ と 1 年以上 $(\bullet$ に分けて, $0^{\circ}$ と $90^{\circ}$ の血行動態諸標の変化を 示卞。

$\mathrm{N}=5(\mathrm{M}+\mathrm{SD})$ 
表 $20^{\circ}$ と $90^{\circ}$ の各症例ごとの血行動態諸標の変化を示す. $\Delta \mathrm{SBP}, \Delta \mathrm{DBP}$, $\Delta \mathrm{HR}$ は実測值で, $\Delta \mathrm{CI}, \Delta \mathrm{SI}, \Delta \mathrm{TPR}$ は $0^{\circ}$ を基準とした時の変化率を\%で 表わしたものである。なお（一）法隇少を示し $\triangle \mathrm{DBP}$ は拡張期血圧 (diastolic blood pressure, DBP) の変化を示す.

\begin{tabular}{crrrrrr}
\hline Case & $\Delta$ SBP & $\Delta \mathrm{DBP}$ & $\Delta \mathrm{HR}$ & $\Delta \mathrm{CI}(\%)$ & $\Delta \mathrm{SI}(\%)$ & $\Delta \mathrm{TPR}(\%)$ \\
\hline 1 & -25 & -9 & 2 & 5 & 2 & -11 \\
2 & -43 & -15 & 11 & -24 & -32 & 3 \\
3 & -22 & 0 & 4 & -19 & -24 & 15 \\
4 & -16 & -1 & -1 & -18 & -16 & 14 \\
5 & -1 & 16 & 12 & -12 & -23 & 28 \\
7 & -29 & -15 & 14 & -11 & -28 & -9 \\
8 & 17 & 9 & 8 & 6 & -4 & 20 \\
9 & 11 & 13 & 1 & -2 & -3 & 54 \\
10 & -43 & -23 & 6 & -31 & -36 & 14 \\
\hline
\end{tabular}

の状態となる ${ }^{5,6)}$. この venous return の減少と心拍出量 の低下をきたし血圧が低下する．しかし健常者では主と して baroreceptor reflex を介する動静脈の収縮や心機 能の元進等により，末梢血管が収縮し心拍出量が維持さ れるため, 血圧はほぼ臥位の時と同程度に保たれる7 9)。 起立性低血圧は，この血圧調節機構の障害が原因である ため, 種及の疾患で出現する。とりわけ中枢性或いは末 梢性神経疾患で多発し，HD 患者にみられる起立性低血 圧についても自律神経障害, 即ち末梢神経障害によると いう報告が多い ${ }^{7,9)}$. しかし有効循環血液量の低下による とするものもいる(0).

一般に成人の起立性低血圧の診断基準については現在

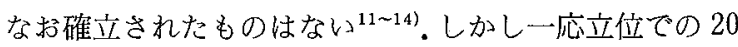
$\mathrm{mmHg}$ 以上の SBP の低下を病的と考えると，これまで の報告 ${ }^{1 \sim 4)}$ に比べて今回は, 10 例中 5 例に認められ，きわ めて高頻度であった，その理由として対象患者が比較的 高齢であったことと糖尿病の合併がまず考えられる. 加 齢と自律神経機能については，これまで数多くの報告が あり，高齢者では起立性低血圧の発生率が高いと言わ机 てきた ${ }^{15,16)}$ 。ただ最近, 起立性低血圧と関連のある疾患な どの risk factor を除くと高齢者にお竹発生は比較的

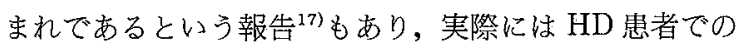
加齢のみによる影響を評価することはきわめて困難であ る。また元来糖尿病は, neuropathy により起立性低血圧 をきたす疾患の 1 つでもあり，特に糖尿病の HD患者で は, tilting test での著明な SBP の低下が報告されてい $ろ^{8)}$.なお今回, 種々の自律神経機能検査を行っていない ためその詳細は不明であるが, これまでの通常の起立性 低血圧の分類 ${ }^{11,19)}$ に従元ば，拡張期血圧に関する限り 5 例中 4 例で低下を認めており，程度の差はあるものの asympaticotonic type に分類できた。

さてこれまで起立試験や tilting test の実施にあたつ
ては，通常 active standing 或いは $40^{\circ} \sim 70^{\circ}$ の一定の角 度を一定時間保持して行う方法が用いられてきた。しか し元来, 起立性低血圧における起立時の血圧低下の程度 は, 下肢静脈の pooling の程度に強く左右されるため, より定量的な評価をするためには角度を変化させること が重要であると思われる。実際健常者で, 毎回 $0^{\circ}$ に戻し て $60^{\circ}$ まで角度を変えて tilting を行った報告によると， 心拍出量は $20^{\circ} て ゙$ 最低となりそれ以上では変化なく, 1 回心拍出量は $60^{\circ}$ まで段階的に低下し, TPR は $30^{\circ}$ まで 増加しそれ以上では変化がなかったとしている20). 即ち 起立時の種々の血圧調節因子は角度の増加, 言いかえれ ぼ pooling の増加に対して同時に同程度に関与するもの ではないことが示唆される。

今回起立性低血圧をきたした 5 例は，角度に対する SBP の変化から 2 つの゙ループに分類できた。まず, $10^{\circ}$ で急激な SBP の低下をきたしたN群では $0^{\circ} \sim 90^{\circ}$ で CI は不変〜軽度低下したが, $30^{\circ} \sim 60^{\circ}$ まで TPR が低下して おり，明らかに末梢動脈の収縮不全を認めた ${ }^{6)}$. 一方, $\mathrm{H}$

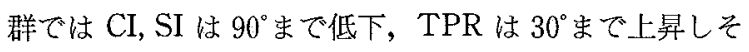
れ以上では一定〜低下, SBP は $30^{\circ}$ まで一定でそれ以上 では直線的に低下した。 この場合, SI とをもに CI も段 階的に低下していることから HR の反応性の低下及び venous return の減少が, 次に $30^{\circ}$ 以上において TPR が 上昇しなかったことより末梢動脈の部分的な収縮不全も 考えられる。即ち症例により程度は異なるが交感神経機 能低下は否定できない。しかし $30^{\circ}$ 以上の SBP の急激な 低下はその反応様式により venous return の急激な減少 そのものを表しているように思われる，通常この原因と して静脈の収縮不全がまず考えられる6. 一般に, 能動的 静脈収縮が静脈内の血液量を減らすのに効果的であるの は静脈が血液によって充満, 伸展している場合とされて いる ${ }^{21)}$. 従って角度の増加につれ pooling が増え, 有効 
な静脈収縮が十分期待できるにもかかわらず，著明に venous return が減少しているとすればむしろ hypovolemia のため効果的な静脈収縮が伴っていない 可能性が大きい, 実際, HD 前後で tilting を行った報 告 ${ }^{22)}$ でも, $\mathrm{HD}$ 前に比べ $\mathrm{HD}$ 後では著明な $\mathrm{CI}, \mathrm{SI}$ の低下 と TPR の上昇, 及び角度の増加による平均血圧の低下 が出現して扔り, HD による除水の影響はきわめて大で あると思われた。今回起立性低血圧をきたした症例のう ち, 角度の増加とともに SBP 及び CI の著明な低下を 認めたH群でも，同様により急角度における有効循環血 液量の減少が示唆された. 従って特にH群に抢ける起立 性低血圧のメカニズムは, 機能的 hypovolemia に対する 自律神経機能による代償不全と考えられ，その血行動態 の変化は, 自律神経機能状態により種々の修飾を受ける ことになると思われる。これは透析低血圧の病態 ${ }^{2226)}$ と 同様と考えられるが，今回検討を行った症例ではこれま で透析低血圧の発症はみていない。次に HD 期間別に比 較してみると，まず $\mathrm{HD}$ 期間が 1 年以上の L 群では起立 後も TPR が低值であるのに対して CI, SI は高值で, SBP の低下は軽度であった。これまで長期 HD 例のう ち常時低血圧では血管反応性の低下 ${ }^{27)}$ が, 高血圧では baroreflex sensitivity の低下 ${ }^{28)}$ が報告されており，起立 時の動脈収縮も不充分と思われる。さらに血行動態的に みると, 通常は CI が高值のため venous return の低下 による血圧低下が影著ではないが, 特に HD 後 hypovolemia に傾くと起立時の CI が著明に低下し, し かも常時低血圧例では軽度のSBP の低下で起立性低血 圧が出現しやすくなると考元られる，ただ HD後低血圧 が体液敨失及び心拍出量減少に対する baroreceptor の 反応性の低下に起因するという報告もある29). 一方 HD 期間が 4 か月以下の S 群では一般に細胞外液が増加して おり，低血圧例が少ないこともあって除水過多の傾向に 楩りやすい。そのため特に HD 導入期には血管内脱水を ひき起こし, 起立的に血圧低下をきたすが, 症状が出現 するに至らないと思われる.特に hypovolemia の関与が 示唆された今回のH群はいずれも HD 開始 1 か月以内 であった。ただ $\mathrm{HD}$ 導入前にみられた自律神経機能障害

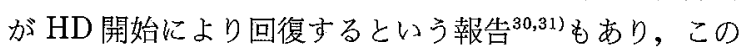
導入期の HD 患者の起立性低血圧に, 自律神経機能障害 がどの程度関与しているか不明である.さらに通常の慢 性貧血の患者の起立試験では著しい TPR の上昇を伴う と報告されている ${ }^{32)}$. HD 患者では貧血の是正による常 時低血圧の改善率はごく小さいものの, 起立性低血圧に 及衩影響については今後検討を要すると思われる。最 後に, HD 患者の起立性低血圧は決してまれではなく, そのメカニズムには HD 患者特有の不安定な体液分布
にもとづく機能的 hypovolemia と自律神経による代償 機能,さらに血管や baroreceptor の反応性が複雑に関 与しているものと思われた。

\section{結語}

1) HD 患者 10 例で, 仰臥位から立位への体位変換時 の循環動態を計測した。

2) $0^{\circ}$ と $90^{\circ}$ のみを比較すると, 糖尿病の 3 例を含む 5 例で $20 \mathrm{mmHg}$ 以上の SBP の低下を，うち 2 例で 40 $\mathrm{mmHg}$ 以上の低下を認めたが, 自覚症状は出現しなかっ た. また HD 後低血圧の症例では TPR は著明に上昇し, SBP はあまり変化しなかった。

3) $20 \mathrm{mmHg}$ 以上の SBP 低下例は角度の増加に対 するSBP の変化から $2 つ の$ pattern に分けられた， 2 例は $0^{\circ}$ から $10^{\circ}$ で低下し, 以後一定, 3 例は $0^{\circ}$ から $30^{\circ}$ ま で一定で以後角度の増加とともに直線的に低下した。 $0^{\circ}$ と $90^{\circ}$ の TPR を比較すると前者では低下, 後者では軽度 の増加を認めた。また同様に CI を比較すると前者では ほぼ不変, 後者では著明に低下した。

4) HD 4 汃月以下の症例に対して，1 年以上の症例 では, 臥位の SBP, TPR が低值で CI は高值であった。 また起立後の SBP, CI の低下はむしろ軽度であった。

5) HD 患者では, 安静時血圧と無関係に無症候性の 起立性血圧低下をきたす場合があり，その原因として自 律神経機能障害のみならず hypovolemia の関与も推定 した。

\section{文献}

1）加藤満利子：透析低血圧の病態に関する研究. 日腎 誌 $29: 1249-1259,1987$

2) Naik RB, Mathias CJ, Wilson CA, Reid JL, Warren DJ : Cardiovascular and autonomic reflexes in haemodialysis patients. Clin Sci $60: 165$ $-170,1981$

3) Cannella G, Picotti GB, Movilli E, Cancarini G, De Marinis S, Galva MD, Maiorca R : Plasma catecholamine response to postural stimulation in normotensive and dialysis hypotension-prone uremic patients. Nephron $27: 285-291,1981$

4) Lamas S, Quereda C, Orofino L, Marcén R, Garcia $\mathrm{F}$, Ortuño $\mathrm{J}$ : Autonomic neuropathy and symptomatic hypotension in hemodialysis patients. Nephron 46 : 107-108, 1987

5) Sjöstrand $T$ : The regulation of the blood distribution in man. Acta Physiol Scand $26: 312-327$, 1952

6) Hickam JB, Pryor WW : Cardiac output in pos- 
tural hypotension. J Clin Invest $30: 401-405,1951$

7) Bradshaw MJ, Edwards RTM : Postural hypotension-pathophysiology and management. QJ Med New Series $60: 643-657,1986$

8) Onrot J, Goldberg MR, Hollister AS, Biaggioni I, Robertson RM, Robertson D : Management of chronic orthostatic hypotension. Am J Med 80 : 454-464, 1986

9) Sobel BE, Roberts R : Hypotension and syncope. In heart disease, a textbook of cardiovascular medicine. Braunwald E (ed) pp 952-963, Philadelphia, 1980

10) Schaz IJ : Orthostatic hypotension. Arch Intern Med $144: 773-777,1984$

11）木川田隆一：低血圧クリニック。新興医学出版社。 東京, 1981

12) Thomas JE, Schirger A, Fealey RD, Sheps SG : Orthostatic hypotension. Mayo Clin Proc $56: 117$ $-125,1981$

13) McDowell FH, Lee JE : Levodopa, Parkinson's disease, and hypotension. Ann Intern Med $72: 751$ $-752,1970$

14) Schellong $F$ : Funktionsprüfung des kreislaufs als untersuchungsmethode. Klin Wochensch $11: 361$ $-366,1936$

15）田村直後, 島津邦男, 稗貫 誠, 大岩海陽, 金浩澤, 濱口勝彦: 自律神経反射に及ぼす生理的加齢の影 響. 日老誌 $19: 563-570,1982$

16) Caird FI, Andrews GR, Kennedy RD : Effect of posture on blood pressure in the elderly. Br Heart J 35 : 527-530, 1973

17) Mader SL, Josephson KR, Rubenstein LZ : Low prevalance of postural hypotension among community-dwelling elderly. JAMA 258 : 1511-1514, 1987

18) Hirakata H, Onoyama $K$, Hori $K$, Fujimi $S$, Fujishima $\mathrm{M}$ : The hemodynamic and humoral responses to tilting in diabetic patients on chronic hemodialysis treatment. Clin Nephrol $27: 298$ $-303,1987$

19) Thulesius $O:$ Pathophysiological classification and diagnosis of orthostatic hypotension. Cardiology 61 (Suppl 1) : 180-190, 1976

20) Tuckman J, Shillingford: Effect of different degrees of tilt on cardiac output, heart rate, and blood pressure in normal man. Br Heart J $28: 32$ $-39,1966$

21）入内島十郎：循環の神経性調節. 問田直幹, 内㝨耕 二編：新生理学(下) pp 265-268, 䀢学書院, 東京, 1975

22) Naik RB, Mathias CJ, Reid JL, Warren DJ : Effect of haemodialysis on the control of the circulation in patients with chronic renal failure. Am J Nephrol 5 : 96-102, 1985

23）平沢由平, 田尻正記, 相沢義房 : 透析低血圧. 腎と 透析 $10: 301-309,1981$

24) Zucchelli P : Hemodialysis-induced symptomatic hypotension. A review of pathophysiological mechanisms. Int J Artif Organs 10 : 139-144, 1987

25) Eiser AR, Swartz $C$ : Hemodialysis and peritoneal dialysis in patients with cardiac disease. In management of the cardiac patient with renal failure. Lowenthal DT, Pennock RS, Likoff W, Onesti G (ed) pp 69-84, Philadelphia, 1981

26) Petitclerc $T$, Drüke $T$, Man NK, Funck -Bruentano JL: Cardiovascular stability on hemodialysis. Adv Nephrol 16 : 351-370, 1987

27) Tajiri M, Aizawa $Y$, Sasaki S, Imai K, Hirasawa $\mathrm{Y}$ : Vascular responsiveness and body fluid status in patients on chronic hemodialysis. J Dialysis 4 : 167-177, 1980

28) Pickering TG, Gribbin B, Oliver DO : Baroreflex sensitivity in patients on long-term haemodialysis. Clin Sci 43 : 645-657, 1972

29) Chen WT, Chaignon M, Tarazi RC, Bravo EL, Nakamoto $\mathrm{S}$ : Hemodynamics of post-dialysis hypotension. Am Soc Nephrol Abstract: 493, 1977

30) Heidbreder E, Schafferhans K, Heidland A : Autonomic neuropathy in chronic renal insufficiency. Nephron $41: 50-56,1985$

31) Campese VM, Romoff MS, Levitan D, Lane K, Massry SG : Mechanisms of autonomic nervous system dysfunction in uremia. Kidney $20: 246$ $-253,1981$

32) Duke M, Abelmann WH: The hemodynamic response to chronic anemia. Circulation $39: 503$ $-515,1969$ 